\title{
Landscapes of Portugal in two hundred years of narratives
}

Ana Isabel Queiroz, IHC and IELT-FCSH, Universidade NOVA de Lisboa

\section{Resumo}

Versando as representações das paisagens portuguesas, retratadas num amplo conjunto de textos que datam do Romantismo até à actualidade, analisam-se convergências existentes entre os conceitos de "paisagem" (o referente) e "paisagem literária" (a representação). São questionadas as diferenças entre o real (uma área) e a expressão criativa de um lugar evocada na literatura (como texto) à luz das diferentes experiências pessoais, informação e contextos socioculturais que modelam as diferentes narrativas dos escritores.

A partir de exemplos de descrições de paisagens em ficção e não-ficção, o artigo trata da forma como os escritores valorizam os elementos naturais e culturais de acordo com suas competências literárias e motivações e no quadro cultural do seu tempo. São analisados excertos de escritores canônicos de literatura portuguesa e respeitados autores atuais: Alexandre Herculano, Júlio Dinis, Camilo Castelo Branco, Eça de Queiroz, Fialho de Almeida, Raúl Brandão, Aquilino Ribeiro, Miguel Torga, José Saramago, Lídia Jorge, Mário de Carvalho e Rui Cardoso Martins.

Como uma descrição romântica ou com uma pretensão de realismo, a vida rural era um tema clássico durante todo o século XIX e XX. Alguns escritores representaram as ameaças iminentes sobre o ambiente natural como consequência de ações humanas, como desmatamento e caça furtiva. Recentemente, a paisagem literária incorporou as profundas mudanças que o país atravessou nas últimas décadas e uma realidade ambiental global, a nível europeu e mundial. As configurações são principalmente urbanas, embora alguma nostalgia para o rural e o "regresso à natureza" possa ser interpretado, em consonância com a cultura atual.

\section{Palavras-chave:}

Paisagem; Literatura Portuguesa; Ecocriticismo. 


\begin{abstract}
Addressing Portuguese literary landscapes depicted in a broad corpus of texts from the Romanticism to the present day, the paper analyses convergences between the concepts of "landscape" (the referent) and "literary landscape" (the representation). Differences between the real (an area) and the creative expression of a place evoked in the literature (as text) are questioned in light of the distinct personal experiences, information and socio-cultural contexts that have shaped different writers' narratives'.

From examples of landscape descriptions in fiction and non-fiction,, the paper focus on the way in which writers valued the natural and cultural elements according to their literary skills and motives, and the cultural framework of their times. Excerpts by canonical writers of Portuguese literature and respected current authors are analized: Alexandre Herculano, Júlio Dinis, Camilo Castelo Branco, Eça de Queiroz, Fialho de Almeida, Raúl Brandão, Aquilino Ribeiro, Miguel Torga, José Saramago, Lídia Jorge, Mário de Carvalho e Rui Cardoso Martins.
\end{abstract}

As a romantic depiction or with a pretension of realism, the rural life was a classical topic throughout the 19th and the 20th century. A few writers represented the impending threats over the natural environment as a consequence of human actions, such as deforestation and poaching. More recently, literary landscape incorporates the profound changes the country has gone through in the last decades, and a global environmental reality in a European and worldwide level. The settings are mostly urban, though some nostalgia for the rural and the "return to nature" can be seen, in line with the current culture of our days.

\title{
Key-words
}

Landscape; Portuguese literature; Ecocriticism.

Years ago, a colleague told me of an episode that happened while she was working on the identification of landscape units. During her field work, she talked to a local shepherd in a rural area, in the border of Southern Portugal. While looking after his flock of sheep on top of a hill, with a view over a broad valley of prairies and bushes, he told her that there was no such thing as a landscape there. The shepherd then apologized, assuming that the 
place he inhabited was somehow flawed, and advised her to look for a landscape elsewhere. The story reminds me of an excerpt from Miguel Torga (1907-1995), in which the writer describes a similar situation:

This afternoon, when I was visiting the Sirol rocky region - a wonder created by the erosion of the waters - and was admiring an extraordinary natural Romanic façade, a villain miller to whom I asked if that didn't appeal to his inner feelings, gave me this exact answer:

- If you have never seen rocks before... ["Hoje à tarde, quando visitava as penedias do Sirol - uma maravilha que a erosão das águas ali fez - e pasmava diante de uma inacreditável fachada românica natural, o bandido de um moleiro, a quem perguntei se aquilo não lhe dizia nada lá por dentro, respondeu-me tal e qual:- Para quem nunca viu pedras... "]. ${ }^{1}$

These two situations mark a starting point for the understanding of the relationship between the referent and the representation, how landscape appreciation is determined by perception and which processes and elements converge for the identification and understanding of landscapes, by common people, writers and those who care about the enhancement and preservation of landscape.

The shepherd and the miller knew the components of their surrounding environments but they did not recognize them in their remarkable dimensions. Used to those places, they could not interpret, nor could they value, the natural and cultural elements of their everyday landscape. The writer and my colleague, on the other hand, who had just arrived to these places, besides appreciating the aesthetic and sensory experience, were able to find significance there.

With the same subject in mind, Michel Collot created the compound word "penséepaysage", which translates into "the relationship that the experience of landscape establishes between a stretch of country and the person who observes it". ${ }^{2}$ In the 1980's, the geographer Denis Cosgrove had already emphasized landscape as a cultural construct and identified the role of perception in this process. He suggested that the landscape could not exist without interpretation because it was both space and meaning. The geographer,

\footnotetext{
${ }^{1}$ Miguel Torga, 'Leiria, 25 de Novembro de 1940', Diário I, in Diário, vols. I- IV (Lisboa: Dom Quixote, 2010), p. 94.

${ }^{2}$ Translated from the French. Michel Collot, La pensée-paysage (Arles: Actes du Sud, 2011), p. 20.
} 
then, understood landscape as "a way of seeing", explaining that there were many ways of seeing the same reality. As such, the same reality could be presented and represented in different ways, and the distance from its referential could vary.

Sanchez de Munian reflected about the relationship between the writer's personal experience and the content of his literary works regarding landscape. ${ }^{4} \mathrm{He}$ stated that Virgil, Camões, Cervantes, San Juan de la Cruz and Shakespeare (and we could still add many others) said what they wanted to say with great strength because they had a firsthand self-knowledge of the matters they were talking about. The British writer Richard Jefferies also wrote: "[i]t is necessary to stay in it like the oaks to know it". 5 David Lowental stated that "conceptions of space" resulted from a combination of perception, memory, logic, faith, learning and imagination, which vary from person to person. ${ }^{6}$ Neil Evernden suggested that a person's vision of Nature (and its representation) was based on his own experience, on the ideas and knowledge of his age, on his occupation and the surrounding components of his environment. ${ }^{7}$ More recently, Marrero Henriquez concluded that "literature on describing the world it decides its formulations". Thus, the literary landscape's values arise from "the poetical quality that lies in the representative capacity of language" ${ }^{\text {. }}$

Without denying the cultural character of representations, ecocriticism studies the relationship between people and the environment, analysing the forms of artistic expression (literary and others) in which this relationship is evident, arguing in favor of a return to referentiality in literary criticism. In this regard, Lawrence Buell wrote: "[s]uch disposition to take the word-world linkage seriously at a time when privileging literature's capacity for mimesis and referentiality remains unfashionable has given rise to

\footnotetext{
${ }^{3}$ D. Cosgrove, 'Prospect, Perspective and the Evolution of the Landscape Idea', Transactions of the Institute of British Geographers 10(1) (1985), 45-62.

${ }^{4}$ J. M. Sanchez de Munian, Estética del paisage natural (Madrid: Publicaciones Arbor, Consejo Superior de Investigaciones Científicas, 1945).

${ }^{5}$ Quoted by J. Hooker, Writers in a landscape (Cardiff: University of Wales Press, 1996), p. 19.

${ }^{6}$ David Lowental, 'Geography, Experience, and Imagination: Towards a Geographical Epistemology', Annals of the Association of American Geographers 51(3) (September 1961), 241-260.

${ }^{7}$ D. Jensen, Listening to the Land, conversations about nature, culture and eros (San Francisco: Sierra Club Books, 1995).

${ }^{8}$ Translated from the Spanish. José Manuel Marrero Henriquez, 'La critica como refugio: animales, plantas y enclaves literários en peligro de extincion', in Lecturas del paisage, coord by José Manuel Marrero Henriquez (Las Palmas: Universidade de Las Palmas de Gan Canaria, 2009), pp. 17-32.
} 
considerable anxiety and division". ${ }^{9}$ To the ecocritical analysis the question is not whether the creators composed their works, but how and why. ${ }^{10}$ This analysis values the presence of the elements the author summoned from the reality that served as his referent. It assumes that the texts, drawings, paintings, photographs, movies or other formats are directly connected with the world. In line with other holistic attempts to understand culture and nature, some ecocritics are in favor of bringing the humanities and sciences together in the context of studying specific landscapes and regions. ${ }^{11}$

Almost three decades ago, the American landscape architect Ervin Zube presented the "transactional model of human/landscape relationship" to explain the process of perceiving (based on information and experience) and responding to environmental change (based on the "personal utility function" and socio-cultural context):

Land form and land use patterns are important sources of information in this process. The distribution of fields, woodlots, hedgerows, water features and buildings and changes in these distributional patterns are perceived differently over time by different individuals. Together with the individuals' range of experiences they shape individual perceptions. And perceptions - mediated by the socio-cultural context in which the person exists and his or her personal utility functions - influence responses to the landscape. ${ }^{12}$

In the universe of meanings from which literature is built, the ability to interpret comes as much from the sensorial and emotional experience, as from a botanical, zoological, geological or cultural knowledge. Despite that, information about the landscape's natural elements is essential, for it defines the way in which it will be mentioned or described: a tree might be depicted as just a "tree" or it might have a more specific designation and description. It might be an oak, a chestnut or a pine tree, it might be an evergreen species or it might be leafless during winter, its leaves might be large or narrow, soft or hard, smooth or stiff. The same can be said about "birds", generically named so or otherwise called by their specific names: sparrows, blackbirds, nightingales, larks, bee-eaters and

\footnotetext{
${ }^{9}$ Lawrence Buell, The future of environmental criticism: environmental crisis and literary imagination (Malden: Blackwell manifestos, 2005), p.31.

${ }^{10}$ I. Smithson. 'Thoreau, Thomas Cole, and Asher Durand. Composing the American Landscape', in Thoreau's sense of place: essays in American environmental writing, edited by Richard J. Schneider (Iowa City: University of Iowa Press, 2000), pp. 93-114.

${ }^{11}$ e.g. William Howarth, 'Some Principles of Ecocriticism', in The Ecocriticism Reader: Landmarks in Literary Ecology, edited by Cheryll Glotfelty and Harold Fromm. (Athens: University of Georgia Press, 1996), pp. 69-91.

${ }^{12}$ E. H. Zube, 'Perceived land use patterns and landscape values', Landscape Ecology 1(1) (1987), 39-40.
} 
many others. And how about shape and size, plumage, singing, nesting, migration, etc.? Will the writer master this kind of knowledge?

From his own perception of, and response to a place, the writer generates a new and specific entity embedded in meaning and symbolism, which is then presented to the reader in the form of a text. Cultural geographers have praised these literary descriptions of landscape and drawn on realistic fiction for evidentiary support. ${ }^{13}$ Historians also read literary works on political crises, conflicts, wars and revolutions to find descriptions of real events in the fictional plot, and to discover if they were set in actual geographical places. Axel Goodbody wrote about the collective experiences subsumed in prose fiction, drama and poetry:

[W]orks of literature are characteristically structured by symbolic figurations of memory. The term "figurations of memory" was introduced by Assmanns to denote a constantly evolving archive of narratives and images deriving from the Bible, Greek myth, fairy tales, history, world literature, etc. These structures, which crystallize meaning around events, people and places, blend factual and textual recall with imagination". ${ }^{14}$

Any landscape summons up intellect, emotion, memories, knowledge and a sensorial experience. To feel a landscape, to think about it, and to interpret it one should look not only at extraordinary landscapes but also at ordinary landscapes, those that Meinig defined as a continuous surface created by and through the "routine lives of ordinary people" 15 , and in which the human element is not only a driver but an intrinsic part of it. The increasing acknowledgment of the need to preserve the landscape values has led to an operational definition, used in regulations, that gathers the subjective and objective dimensions of landscape, and the inherent mechanisms of appreciation and understanding. According to the European Landscape Convention, "landscape is part of the land, as perceived by local people or visitors, which evolves through time as a result of being acted upon by natural forces and human beings. (...) Each landscape forms a blend of components and structures: types of territories, social perceptions and ever-

\footnotetext{
${ }^{13}$ At least since J.K. Wright who called for the need to teach geosophy in the univerties or colleges; J.K. Wright, 'Terrae Incognitae: The Place of Imagination in Geography', Annals of the Association of American Geographers 37 (1947), 1-15.

${ }^{14}$ Axel Goodbody, 'Sense of place and lieu de mémoire: A cultural memory approach to environmental texts', in Ecocritical Theory. New European approaches, ed. by Axel Goodbody and Kate Rigby (Charlottesville and London: University of Virginia Press, 2011), pp. 57-9.

${ }^{15}$ D.W. Meinig, The Interpretation of Ordinary Landscapes: Geographical Essays. (New York, Oxford: Oxford University Press, 1979).
} 
changing natural, social and economic forces". ${ }^{16}$ Despite its non-universal acceptance, this landscape concept includes urban and rural, ordinary and extraordinary, preserved and degraded landscapes: any landscape is an entity with intrinsic value, regardless of the elements composing it or the extent to which it is recognized. Likewise, today, the ecocritical analysis devotes itself to the study of contemporary texts, practicing the so called "second-wave ecocriticism"17, which, as Michael Bennett strongly advocates, includes as its objects of study all kinds of literary landscapes ${ }^{18}$.

Addressing Portuguese literary landscapes depicted in a broad corpus, from the Romanticism to present, this paper examines the literary landscape elements. Over this period of almost two hundred years, landscape representations, mediated by individual perception and the creative process, remained present in the literary narratives.

For the purpose of this argument, a sample of landscape writers and their landscape writings are presented here. This article constitutes an overview of the landscape in Portuguese literature and aims to present the evolution of representations, in terms of the form, content and scale in which they are described, and to identify the issues that may alter its constituent elements. Three periods of analysis were established, in which different aesthetical and ideological trends were followed.

This exercise explores the literary excerpts of landscape descriptions compiled by the collective project LITESCAPE.PT - Atlas of Literary Landscapes of mainland Portugal (https://ielt.fcsh.unl.pt/paisagensliterarias/). Making a general review, it takes the same risks as all other samplings, as it tries to be comprehensive without being exhaustive, selective without being discriminatory, and illustrative without being misleading. Inevitably, more will be the writers and the works that will be left out than those who will find a space in this text.

\section{The $19^{\text {th }}$ century}

In a time when the valuation of rural life reappears as a reaction against the urban and industrial development - a classical topic fostered by several Portuguese thinkers Alexandre Herculano (1810-1877) emerges as one of the most acclaimed exponents of the Romanticism in Portugal. On a fluvial trip in Tagus River, "in a slow-moving ship",

\footnotetext{
${ }^{16} \mathrm{http}: / / \mathrm{www} . c o e . i n t / \mathrm{en} / \mathrm{web} /$ landscape/the-european-landscape-convention)

${ }^{17}$ Buell 2005.

${ }^{18}$ Michael Bennett,"From Wide Open Spaces to Metropolitan Places: The Urban Challenge to Ecocriticism" ISLE, 8 (winter2001.): 31-52.
} 
the author described the surrounding pastures of the marshy lands as if they were a work of art:

The bull herds, solemnly still on the margins, or immersed in the water, between the slender reeds and the rushes, seemed to observe the river movement, (...) and in their slow movements (...) no one would ever guess their ferocious nature. In the clear sky, in the changing colors of the bare lands, in the several shades of green of the vegetation, in the whisper of the wind one could feel a peaceful harmony, a life without storm. [As manadas de touros, parados gravemente pela margem, ou metidos na água por entre os caniços e juncais, pareciam observar o movimento do rio, (...) nos seus meneios lentos (...) ninguém lhes adivinhava a nativa ferocidade. Na limpidez do céu, nas tintas cambiantes das terras calvas, nos verdes variados da vegetação, no murmúrio do vento havia uma harmonia de paz; havia vida sem tempestade. "] ${ }^{19}$

The aestheticization of Nature is very clearly conveyed in this excerpt through the transcendent representation of common elements (the bulls, the vegetation, the river water, the sky, the wind) which are considered beautiful and sublime.

In contrast to, and often in satire of urbanism, other authors of the period also praised the agricultural landscape. That is the case of Júlio Dinis (1839-1871). The main character of one of his well-known novels, A Morgadinha dos Canaviais, 1896, is an urban idler who travels to a village in the North of Portugal to recover from a "city illness". After some time in an illustrious homestead, where his idleness persists, he turns into a dreamer of the alleged countryside serenity. An ecocritical analysis of landscapes in Portuguese literature, by Isabel Alves, suggests that the ideological context of Júlio Dinis and other romantic writers" works provides the basis for this rural novel diegesis: "[the] natural theology, which defined the Portuguese vision of nature, [is] accentuated by the profound belief that landscape - a humanized place - is effectively a book in which man's action may be read and his secret aspirations revealed". ${ }^{20}$

The first Portuguese realist writers rose when eminent romantics were still producing their literary work. Among them, Eça de Queiroz went down as a portraitist of the Lisbon society of the 19th century, setting in which the plots of most of his novels occur. However, he recovers the topic of countryside versus city in one of his most accomplished works, The City and the Mountains [A Cidade e as Serras 1901, posthumous]. In this novel,

\footnotetext{
19 Alexandre Herculano, Cenas de um ano da minha vida. Poesia e Meditação. [1831-1832]. Apontamentos de Viagem [1853-1854] (Lisboa: Bertrand Editora, 1973), p. 189.

${ }^{20}$ Isabel Alves, Landscape: inter-relationships between place and soul (Cluj-Napoca: Editura Limes, 2006).
} 
the author opposes Paris, where he lived in the last years of his life and where he was Consul of Portugal, to the Douro region (Baião, Portugal), where his wife's family came from. He creates a clear image of Tormes (the family estate), which appears before the reader as an exercise of observation and detailed analysis of reality. However, the writer did not know the place he was describing very well, since he only visited it once and only for a short period of time, so we may well suppose that the setting was at least partially imagined.

In his pretension of realism, which distinguishes him from his predecessors, he lists common elements (the vineyards in terraces, the orange tree groves, a chapel, the river stream), pointing out chromatisms, directions and proportions, without forgetting to suggest, through the character's reactions, the aesthetical dimension of the setting:

(...) terraces planted with vines (...) a fine house, a lace of opulent repose, with a little whitewashed chapel set in a grove of orange trees full of ripe fruit. On the river, where the dark, desultory waters did not even break against the rocks, a boat in full sail and laden with barrels was making its slow way downstream. Farther off, where olive trees were dwarfed by vast mountains, other fields - the pale green of mignonette - rose up to meet bare, sun-baked rocks drinking in the fine abundance of blue. Jacinto was still stroking his moustache.

"The Douro, eh?? Very interesting".

[“(...) socalcos cultivados de vinhedo (...) uma casa nobre, de opulento repouso, com a capelinha muito caiada entre um laranjal maduro. Pelo rio, onde a água turva e tarda nem se quebrava contra as rochas, descia, com a vela cheia um barco lento carregado de pipas. Para além, outros socalcos, de um verde pálido de reseda, com oliveiras apoucadas pela amplidão dos montes, subiam até outras penedias que se embebiam, todas brancas e assoalhadas, na fina abundância do azul. Jacinto acariciava os pêlos corredios do bigode: -O Douro, hein?... É interessante!"'] ${ }^{21}$

Fialho de Almeida (1857-1911), a protagonist of the Naturalism trend, broke with the traditional bourgeois and aristocratic novel (of which the work of Eça de Queiroz is an example) awarding his leading roles to the poorest and most disadvantaged. In one of his short stories set in Lisbon, the writer describes a fair, a place of popular entertainment near the Prazeres cemetery: daughters wearing ironed skirts, with deep dark circles, Fado singers wearing stretched pants over linen espadrilles, fat women wearing red scarves,

\footnotetext{
${ }^{21}$ Eça de Queiroz. The City and the Mountains, trans. by Margareth Jull Costa (New York, New Directions Book, 2008), p. 140.
} 
with naked thick arms braising mussels, flushing in the heat; beastly common face soldiers telling rude things to dirty little fish-sellers; dirty child beggars, workers' families nibbling something over the grass, skeletal bums selling water, etc. ${ }^{22}$ As Julia Barella Vigal points out referring to Naturalism in Spanish literature, here also, "landscape defines and determines those who inhabit it". ${ }^{23}$

In opposition to the city, Fialho de Almeida also writes about the countryside and his passion for the rural life:

In August (...) a countryside nostalgia comes to the minds of those like me who possess within, under the artificial enclosures of a thinker and an articles writer, the pure, simple and contemplative soul of a villager led astray from his fields cultivation and of a captive farmer, always sighing for his plough.

[Em Agosto (...) Lisboa está deserta (...) uma nostalgia de campo acode ao espírito de quem, como eu, tem cá dentro, sob os invólucros postiços dum pensador e dum artigoleiro, a alma cândida, contemplativa, simplória, dum aldeão transviado à cultura dos seus campos e dum lavrador cativo, que a todos os instantes suspira pela rabicha do arado. $]^{24}$

Moving away from the dominant theme that favoured an urban versus rural dichotomy, Raul Brandão (1867-1930) was the first to literarily describe the sea, the coastline and the fishermen's lives, going against the most usual landscape overview of the time in Portugal. His experience in Foz do Douro, where he was born a son and grandson of seamen, marks the way in which he represents the country and its people throughout his work: "this landscape - sea, river and sky - is deeply ingrained in my soul, not as a landscape but as a feeling" [ "esta paisagem-mar, rio e céu-entranhou-se-me na alma, não como paisagem, mas como sentimento"']. ${ }^{25}$. His relationship with Nature had already been conveyed in previous works: "I have never been so moved before anything as before the humblest of the trees" [ "nunca me comovi como diante da árvore mais humilde"]. ${ }^{26}$ In the Preface to the first volume of his Memoirs (Memórias, 1919) he also wrote: 'I'm incapable of looking at a tree without wonder" ["não posso ver uma árvore sem

\footnotetext{
22 Fialho de Almeida, 'A Ruiva', in Contos (Porto e Braga: Livraria Internacional de Ernesto Chardron, 1881, 1st edition), p. 18.

${ }^{23}$ Translated from Spanish. Julia Barella Vigal, 'Naturaleza y paisaje en la literatura espanhola', in Ecocríticas. Literatura e medio ambiente, ed. by C. Flys-Junquera and others (Madrid: Iberoamericana, 2010), p. 230.

${ }^{24}$ Fialho de Almeida, O país das uvas (Lisboa, Círculo de Leitores, 1992), p. 27.

${ }^{25}$ Raul Brandão, Os Pescadores (Lisboa: Livraria Bertrand, 1923), p. 21.

26. Raul Brandão, Os Pobres (Lisboa: Empresa da História de Portugal, 1906), p. 106.
} 
espanto"], further declaring: "I am perhaps a tree growing at its will, a branch over here, a branch over there" ["sou talvez uma árvore que cresce à vontade, pernada para aqui pernada para acolá "]. ${ }^{27}$ Academics who study his works recognize in him the influence of Russian authors. He could be described as a "Dostoevskian" researcher of the mysteries and riddles of the human soul, ${ }^{28}$ who searched for answers in the natural environment.

While echoing romantic and symbolist tendencies, Raul Brandão also took upon himself the endeavour of unveiling and depicting the country through his landscape descriptions. In 1926, the author published The Unknown Islands (As Ilhas Desconhecidas), a book where he described the Azores islands and the people's way of living. In 1929, together with his wife, Maria Angelina, he signed the work Small Size Portugal (Portugal Pequenino), a text we could nowadays call an "ecological portrait". Written for children - more specifically "for other people's children", as it is revealed in the dedication - this novel presents a world in which nature and fantasy are entwined. ${ }^{29}$

In a section of the book, the protagonists become the last pack of wolves inhabiting the Marão range. The wolves have nothing to hunt for, they are chased by humans and their pups are starving. The concerns we now call "environmentalist" are quite clear. In fact, the novel presents some impending threats over the natural environment which are a direct consequence of human actions:

The Forestry (Department) killed wolves which were one of the most extraordinary expressions of those hills and their favorite offspring. It poisoned them because they were thought to be many and were thought to be useless. Well, the wolf is a character that is indispensable to the hills. To the hills and to life itself. Without them, the Marão [range] looks more uninhabited and something is missing from the life of the imagination which diminishes man rather than exalting him.

[“A florestal matou os lobos que eram uma das expressões mais extraordinárias da serra e os seus filhos dilectos. Envenenou-os por serem muitos e os julgar inúteis. Ora o lobo é uma figura indispensável à serra. À serra e à vida. O Marão, sem eles, parece mais despovoado e à vida de imaginação falta qualquer coisa que apouca o homem em lugar de o engrandecer." ${ }^{30}$

\footnotetext{
${ }^{27}$ Raul Brandão, Memórias I (Porto: Renascença Portuguesa, 1919), p.9 and 24.

28 Translated by the Portuguese. Guilherme Castilho, 'Dostoievsky e Raul Brandão', Sep. Memórias Acad. Ciências Lisboa. Classe Letras 23 (1983), 145.

29. João Pedro Andrade, Raul Brandão - a obra e o Homem, (Lisboa: Acontecimento, 2002).

${ }^{30}$ Maria Angelina and Raúl Brandão, Portugal Pequenino (Lisboa: Vega, 1985), p. 53.
} 
These feelings of respect, acknowledging the wolf as part of a brotherhood, recognizing its intrinsic value and right to exist, might be interpreted as conservationist values, which are pioneer in the Portuguese cultural and scientific milieu ${ }^{31}$.

\section{The $20^{\text {th }}$ century}

The rural provenance of many of the twentieth century writers seems to be the main reason why many literary landscapes of the first half of the twentieth century were still countryside representations. They demonstrated the mosaic of land use and local human activities like agriculture, pastoralism, forestry, hunting, fishing, etc. Although most regions of the country were depicted in the literary sceneries of narrative production of the time, in each writer's work, a local landscape, often associated with his birth place, seemed to prevail.

In this panorama, Aquilino Ribeiro (1885-1963) stood out, due to his clear appreciation of the natural elements of landscape, flora, fauna and geology, his respect for nature and landscape, and his recognition of the destroying action of humans over animals and plants. After a few fictional works in which landscape was a character, revealed by how its presence in the text conditioned the narrative's pulse and determined its action, the writer wrote literary itineraries of the places he knew and the experiences he lived, composing repositories of episodes and stories of village people, through which he expressed his opinions on ideas and usages that were damaging to the environment. ${ }^{32}$ While observing the hills that he thought were once covered with oaks and chestnuts he noticed that the vegetation, that had been gradually disappearing, had left "the hills once dressed in the movable and foaming green of the woods [...] appallingly naked". ${ }^{33}$...About deforestation, the author produced ecological, economic and aesthetic arguments:

All these hills, now naked, played a necessary role. Dressed in forest, they were wonderful humidity condensers. Besides that, they offered a shelter against coldness, so that the ditchers would manage to work on the delicate cultures. And these same hills, in the slopes facing the sunny side, became extremely fertile orchards. (...) Bad decisions, greed and the clearing of land have gradually depopulated the hills, latently

\footnotetext{
${ }^{31}$ Margarida Lopes-Fernandes and others, 'Living with the Beast: Wolves and Humans through Portuguese Literature', Anthrozoös 29(1) (2016), 5-20.

${ }^{32} \mathrm{eg}$. the four books of chronicles: Village - Land, people and animals (Aldeia-Terra, gente e bichos, 1946), Sentimental Geography (Geografia Sentimental, 1951), Leathered Chests (Arcas Encoiradas, 1953) and The Man of the Ship (O Homem da Nave, 1954).

${ }^{33}$ Aquilino Ribeiro, Aldeia. Terra, gente e bichos (Lisboa, Livraria Bertrand, 1964), p. 118.
} 
affecting the prosperity of local residents and its beauty. The juicy earth has flown out to the rivers that rolled it to the sea. It became stone. More than half of Portugal is made of bones. [Todos estes montes, hoje descarnados, exerciam uma função necessária. Vestidos de floresta eram admiráveis condensadores de humidade. Ofereciam, além disso, agasalho contra a friagem, para que os valeiros se prestassem às culturas melindrosas. Eles mesmos, nas encostas orientadas a sabor do soalheiro, tornavam-se em fecundíssimos vergéis (...) Maus passos, cupidez, o arroteamento foram despovoando os montes, com prejuízo latente da prosperidade dos moradores e da beleza. A terra suculenta escorreu para os rios que a rolaram para o mar. Ficou pedra. Mais de metade de Portugal é ossatura.] ${ }^{34}$

In his estate at Soutosa (Moimenta da Beira), living beings were valued for their utility to humans (as food, means of transportation or workforce), their intrinsic value and the role they played in Natural History: "[1]and, corn, cultivation types are transitory. Birds and plants, the beautiful plants of the woods already reach eternity, at least in what concerns my life, and to birds I vow the same respect, considered in their zoological succession". ${ }^{35}$ The author himself took measures to preserve animals: “(...) I have strictly forbidden harming animals inside the farm. (...).And not harming them meant not taking away their nests, nor scare them with scarecrows or vanes, least of all set them on fire. Just as in Kruger Park". ${ }^{36}$

In the same rural matrix, Miguel Torga's literary landscape emerges from a wide corpus. His relationship with the Portuguese territory is one of the most surprising aspects of his landscape writing. Like Raul Brandão, the writer devised a road map of the country, region by region, drawing its physical and human portrait. Portugal (1950) rose from a critical positioning regarding the political regime (from which he was a direct victim) ${ }^{37}$ and from his deep personal knowledge of places and their inhabitants. The poem "Motherland" ("Pátria") precedes the narrative, bringing affective resonances of the author's landscape experiences in this "stretch of land, embroidered with waves", despite his tough and painful childhood and despite emigration, or maybe because of it, for it led

\footnotetext{
${ }^{34}$ Aquilino Ribeiro, Geografia Sentimental (Lisboa, Livraria Bertrand, 1985), p. 222 and p. 284

${ }^{35}$ Geografia Sentimental, p. 327.

${ }^{36}$ Translated from Portuguese. Aquilino Ribeiro, O Homem da Nave (Lisboa, Livraria Bertrand, 1968), p. 147.

37 the authoritative, antiparliamentary and anti-liberal political regime, designated as 'Estado Novo' ('New State'), held in Portugal from1933 to 1974)
} 
him to discover other geographical places. While addressing both the "regional" and "national", Torga brought forth the worldview of an educated man who was aware of the problems of his country and the world. ${ }^{38}$ Additionally, the writer understood the temporal dynamics of landscape in its natural and cultural components and assumed himself as a "memories fastener" ["fixador de memórias"]:

Confined by the human reality of the moment, I have romanticized Douro River troubled by classes, injustices, sweat and misery. And that Douro fortunately is about to change (...) Gone are the tyrannical employers, the degrading little houses at ground level and starvation wages. (...) Even the river has lost his gushes, drowning into calmness reservoirs.

[ "Cingido á realidade humana do momento, romanceei o Douro atribulado, de classes, injustiças, suor e miséria. E esse Douro, felizmente, está em vias de mudar. (...) Desapareceram os patrões tirânicos, as cardenhas degradantes, os salários de fome. (...) Também o rio já não tem cachões, afogados em albufeiras de calmaria.] ${ }^{39}$

During this period, the harshness of the peasants' lives was portrayed depending on political and ideological positioning. ${ }^{40}$ Rural landscapes were used as symbols of nationality by the official propaganda. Idealized as "calm and discrete, almost childish" 41 , peasants were supposedly happy in their daily work and showed elevation of spirit and deep religious feelings. At the same time, Neo-Realism was engaged in a social context that, at its onset, focused mainly on the rural environment. This movement would come to distinguish itself by "highlighting the heroism of those who are the means for social transformation". ${ }^{42}$

With the same ideological positioning, Raised from the Ground [Levantado do Chão] (1980), by the Nobel prize José Saramago, devotes its first chapter to landscape. Landscape is "the support and modeling agent of the narrative", where the reader can "draw not only the physical geography of the territory but also and mostly discover a geography of affections, the private sphere supporting and opening the way to the political

\footnotetext{
${ }^{38}$ See the previous note for the quotations' reference. The autobiographical work The World's Creation (A Criação do Mundo, 1937-1981) is, in this regard, also an enlightening element.

39. Miguel Torga, 'Prefácio à tradução Inglesa', Vindima (Lisboa: Dom Quixote, 2003).

${ }^{40}$ A.I Queiroz and J. Carrilho, "Stone Metaphors about a Village: a 'Stone Vessel' or 'The Most Portuguese", Ecozon@, 2 (1) (2011): 13-33.

${ }^{41}$ Carlos Queiroz, Landscapes of Portugal (Lisboa, Secretariado Nacional de Informação, 1940), p. 13.

42 A. Pinheiro Torres, "Neo-Realismo (1935-1950)" in História da Literatura Portuguesa. As Correntes Contemporâneas, volume7, edited by Óscar Lopes and Maria de Fátima Marinho, (Lisboa, Publicações Alfa, 2002), p. 183-234.
} 
struggle" ${ }^{43}$. The author tells us that landscape "clearly pre-dates man", that "it's constantly changing: at certain times of the year, the land is green, at others, yellow or brown or black. And in certain places it is red, the colour of clay or spilled blood"44 [(..) porquanto a paisagem é sem dúvida anterior ao homem, e apesar disso, de tanto existir, não se acabou ainda. Será porque constantemente muda: tem épocas do ano em que o chão é verde, outras amarelo, e depois castanho, ou negro. E também vermelho, em lugares, que é cor de barro ou sangue sangrado.], a description in which the symbolic infects the real: the expression "spilled blood" is a clear allusion to conflict, suffering and repression, which are the main themes of the novel, set before the Carnation Revolution (25 April 1974) that freed the country from a dictatorial regime.

Words used to describe landscapes are a dynamic resource that can disappear for lack of usage, for lack of a physical and ecological reference to match it with. The Spanish writer Miguel Delibes stated, three decades ago, that he feared people would soon need to read his books with clarification notes, as if his text had been written in an archaic or esoteric language. ${ }^{45}$ In this respect, José Saramago reinforces the value of words, explaining that, at a time when most people live in cities, the right terms are what give a literate his right dimension to rural landscape representations: "we've mentioned some already, and now we add others for the purpose of general enlightenment, because townspeople think, in their ignorance, that it's all a matter of sowing and harvesting, well, they're much mistaken unless they learn all the other verbs involved and realize just what they mean $[\ldots]^{\prime \prime} \cdot{ }^{46}$

\section{The $21^{\text {th }}$ century}

Since 2000, Portuguese novels have been characterized by a vast plurality of genres, themes and styles, which can be grouped according to the concept of cosmopolitanism $^{47}$. Among other definitions, the term came up in the ecocritic theory as "a way of imaging

\footnotetext{
${ }^{43}$ Translated from the Portuguese. Fernanda Cunha, A paisagem e as palavras que lá estão. Levantado do Chão, um romance político (Lisboa: Apenas Livros, 2012).

${ }^{44}$ José Saramago, Raised from the Ground, trans. by Margareth Jull Costa (London: Harvill Secker, 2012).

${ }^{45}$ Miguel Delibes, El sentido del progreso desde mi obra (Barcelona: Destino, 1975).

${ }^{46}$ José Saramago, Raised from the Ground, trans. by Margareth Jull Costa (London: Harvill Secker, 2012).

${ }^{47}$ Miguel Real, O Romance Português Contemporâneo 1950-2010, (Lisboa: Caminho, 2012).
} 
forms of belonging beyond the local and the national". ${ }^{48}$ These Portuguese literary landscapes incorporate the profound changes the country underwent, during the last decades, by influence of a globalized reality on a European and worldwide scale. The settings are mostly urban, though some nostalgia for the rural and "the return to nature" can be seen, in line with the current popular ideas of ecological and spiritual restoration. The depiction of landscape patterns and their modification processes play a less relevant role, although the natural and cultural contexts that arise from them and some environmental concerns are still crucial to the development of the story. To illustrate, three novels from three contemporary writers are examined.

Lídia Jorge was born in Algarve in 1946. During her life in that region she witnessed the emigration of the poor, the abandonment of the fields and the development of mass tourism, phenomena characteristic of the 1950s and 1960s. The Migrant Painter Of Birds (Vale da Paixão, 1999) introduces a family of small agricultural landowners going through changes dictated by the transformation of the rural environment. One of the characters tries to resist, maintaining cultures and modernizing them. But the emigrant brother has a different perception of the future:

That it wasn't worth investing in mechanization on such scattered lands, separated by distance and by high stone walls. They should invest in the leisure industry before others got in on the act. Leisure was where the money would be. Leisure would be the next great source of wealth, the great engine of development and change in the world. Leisure would be a way of life, an aim, a cause..$^{49}$

["Que não valia a pena iniciar a mecanização em terras dispersas, separadas umas das outras por quilómetros de distância e altos muros de pedras. Antes que outros assaltassem essa indústria, eles deveriam investir no sector do lazer. O lazer e o ócio, era tudo o que daria dinheiro. O lazer iria ser a grande fonte de riqueza, a grande fonte de desenvolvimento, de mudança, de alteração do mundo. O lazer iria ser um modo de vida, uma finalidade, uma causa. ']

In order to represent a transforming landscape, the writer summons prodigious facts, in a magical realism frame, thus expressing damages to the harvests and the biodiversity and revealing the erosion of the bare soil:

\footnotetext{
${ }^{48}$ Ursula Heise, Sense of Place and Sense of Planet. The Environmental Imagination of the Global (Oxford, Oxford University Press, 2008), p.6.

${ }^{49}$ Lídia Jorge, The Migrant Painter Of Birds, trans. by Margareth Jull Costa (London: The Harvill Press, 2001).
} 
The birds from the mudflats, fleeing the earth-moving work going on near the dunes, turned up in large, disoriented flocks in the dried stubble fields, laying their eggs out of season and in the wrong places. Certain weeds disappeared, while other unknown varieties proliferate. The ripening figs split into nine segments, the green olives remained black and thin for lack of rain. The earth was so dry. He watched the wind lifting the earth into the air and carrying it off to other places, he watched the arable soil growing thin $[\ldots]^{50}$

[[a]s aves do sapal que se levantavam das terraplanagens, perto das dunas, apareciam caminhando no restolho sequeiro, vesgas, tresmontadas, pondo ovos fora do tempo e do lugar. Umas ervas desapareciam, outras que nunca tinha visto alastravam. Os figos amadureciam abertos em nove partes, as azeitonas verdes ficavam bicudas e pretas pela falta de chuva. Seca, a terra seca. Ele via o vento levantar a terra no ar, transportála consigo para outras paragens e a espessura do solo arável emagrecer e descamarse. De pé, no meio do monte, ele via o que ninguém via - a terra a elevar-se no ar (...).] Mário de Carvalho was born in Lisbon, in 1944, in a family from the Alentejo region. He regarded changes in urban and rural landscapes with a highly politicized, critical positioning. Fantasy for two colonels and a swimming-pool (Fantasia para dois coroneis e uma piscina, 2003) raises the question of the "new rurality": how the countryside is once again brought to life, but this time as a recreational place instead of a working or production place. The reader is led to question the exercise of power (e.g. authority and wealth), the decision making process and the people's participation in the construction of society. Two retired army colonels move to Alentejo and refurbish montes (the typical architectural ensemble of agricultural estates in this Southern region of Portugal), to try to fulfil their desire of creating an idealized countryside and to show off some prosperity emblems, symbolically represented by the swimming-pool, where no one bathes. Then, landscape changes:

Down there, in the landscape inlaid in the extremely rough permanence of things, where only high castles, menhirs and cromlechs rule, the bluish transparent and very modern swimming-pool clashes and startles. It is treated with expensive and specious fluids [...] a kind of skylight, clashing with the landscape, made of meadows and thickets of dwarf oaks lulled by disperse flock bells.

[Lá em baixo, na paisagem, incrustada na duríssima permanência das coisas, onde só mandam altos castelos, menires e cromoleques, destoa azulínea, e sobressalta com a

\footnotetext{
${ }^{50}$ Lídia Jorge, The Migrant Painter Of Birds, trans. by Margareth Jull Costa (London: The Harvill Press, 2001).
} 
transparência, a piscina, modernaça e tratada a poder de fluidos caros e especiosos (...) espécie de olho de boi, desnaturado na paisagem, que é de prados e chaparrais, embalados por badalos espaçados de rebanhos. ${ }^{51}$

The countryside becomes a new globalized reality. Their basic needs, as well as their needs for comfort, can be easily fulfilled with a drive to the ATM or the supermarket in the nearest village. The idleness of the everyday life moves the characters' concerns away from their place of residence. This neo-rural environment, where the traditional work tasks that characterized it are completely absent, becomes a place where garbage collection and the moral basis for the killing of wild species become everyday topics.

Let an Invisible Man Pass (Deixem passar um Homem Invisível, 2009), by Rui Cardoso Martins tell us about a flood (coincidence or not, the writer was born in 1967, the year in which Lisbon suffered the worst flood of most recent times). The novel criticizes the way in which the capital's urban expansion led to the occupation of flood risk areas, with consequences for people's safety and environmental quality:

The peaks of rainfall - real or imaginary - provoke floods, above all because Lisbon has expanded along an uneven hilly terrain without having observed required physical planning nor showing any concerns for environmental respect.

[Os picos de precipitação - os reais ou os imaginados - originam cheias, sobretudo porque Lisboa se expandiu ao longo de uma orografia acidentada e sem as requeridas medidas de ordenamento e respeito ambiental. ${ }^{52}$

Besides the lack of planning, the writer lists other territorial management issues which do not seem to have been properly addressed:

Lots of exits were clogged with new buildings, concrete, shacks and walls. Others were covered with garbage, underground garages dug by night in the stream beds (...). In the Chelas valleys, alongside the cabbage and turnip greens gardens, the submerged stems stuck in the soil like flags, viaducts and pilasters were sinking, put on the wrong place by someone's order

[ "Muitas saidas estavam entupidas com prédios novos, betão, barracas e muros, outras cobertas de lixo, garagens subterrâneas escavadas à noite no leito dos riachos (...). Nos vales de Chelas, ao lado das hortas de couve e nabiça, dos talos submersos espetados no solo como bandeiras, afundavam-se viadutos e pilastras erguidos no sítio errado por ordem de alguém". $]^{53}$

\footnotetext{
${ }^{51}$ Mário de Carvalho, Fantasia para dois coronéis e uma piscina (Lisboa: Caminho, 2003), p. 19.

52. Rui Cardoso Martins, Deixem passar o Homem Invisível (Lisboa: Dom Quixote, 2009), p. 11.

${ }^{53}$ Deixem passar o Homem Invisível, p. 17-19.
} 
It is in this daily landscape, and because of it, that a big hole forms on the street pavement. The waterproofing of a great part of the urban soil leads to the flow of unbearable quantities of rain into the subterranean ducts in moments of very intense rainfall, causing these structures to burst and the earth above them to sink down. The Fire Chief, who is in charge of the rescue team, resorts to history to explain the accident suffered by the missing characters:

[d]on't forget this happens when it pours as wildly as that, this is an extremely poorly made city at surface and subsurface level, full of streams tamed through giant water pipes, which is not and has never been ready for rainfalls.

[[n] ão se esqueçam que isso sucede quando chove desta maneira louca, é uma cidade toda mal feita no solo e subsolo, cheia de ribeiras domesticadas com canos gigantes, que não está nem nunca esteve pronta para precipitações. $]^{54}$

Rui Cardoso Martins, like many other contemporary writers who contributed to the literary imagery of Lisbon in the twenty-first century, portraying the city as it was lived and experienced, does not turn away from the discussion on the vulnerabilities inherent to the concentration of population and the inevitable reflection on the environmental sustainability issues. Upon the urban landscape falls a critical eye that both aestheticizes the social and the constructed monumentality, and marks the denaturalization, lack of planning and degradation. In the framework of the current literary representation, the urban area is a planetary place. ${ }^{55}$

\section{Conclusion}

In their exercise of construction of the literary text, Portuguese writers ascribed to landscape different ways of expression and different roles in the narratives' composition, in line with a chronological alignment and the artistic and ideological movements from each temporal context. However, the extended study of literary landscapes does not reveal its transformation only on an aesthetic or political level.

From the twentieth century onwards, the scales, themes and issues summoned during the construction of the narrative's sceneries, or related to them, started to reflect the changes of the landscapes that served as their referential. The local (or regional) landscape is, then,

\footnotetext{
${ }^{54}$ Deixem passar o Homem Invisível, p. 21.

${ }^{55}$ A.I. Queiroz, Planeta Lisboa in Falas da Terra no século XXI. What do we see green?, edited by A.I Queiroz and I.O.Castro (Lisboa: Esfera do Caos, 2011), pp. 145-161.
} 
the object of the writer's attention. The first half of the twentieth century already witnessed concerns over the dynamics induced by the overexploitation of natural resources, which harm soils, vegetation, some animal species and the human populations from the affected areas.

The record of urban experiences from different social classes plays witness, throughout the twentieth century, to the building expansion and the attraction of people, namely writers, from rural to urban spaces (especially Lisbon) and coastline areas.

The national and global scale phenomena that impacted the landscape and triggered the environmental concerns which emerged in the last decades of the twentieth century, have only recently found a place in Portuguese literature. In line with a growing social awareness and a set of new public policies, these texts in particular, cast a critical eye over the processes of construction and deconstruction of the landscape values, highlighting the need to correct some practices that are not respectful to the environment or the quality of life. Literary works from the twenty-first century align themselves with a general trend that Lawrence Buell calls "eco-globalist", derived from "ecoglobalism, a whole-earth way of thinking and feeling about environmentality" 56

\footnotetext{
${ }^{56}$ Lawrence Buell, Ecoglobalist Affects: the emergence of U.S. Environmental Imagination on a Planet Scale in Shades of the planet: American Literature as world literature, edited by W.Dimock and L.Buell (Princeton and Oxford, Princeton University Press, 2007), p.227.
} 